\title{
Differences in lung function and prevalence of pneumoconiosis between two kaolin plants
}

\author{
M E BASER, T P KENNEDY, R DODSON, W RAWLINGS JR, N V RAO, J R HOIDAL \\ From the Department of Environmental Health Sciences, Johns Hopkins School of Hygiene and Public Health, \\ Baltimore, Maryland, Pulmonary Medicine Division, University of Tennessee, Memphis, Tennessee, and \\ Department of Environmental and Cell Biology, University of Texas Health Sciences Center, Tyler, Texas, USA
}

ABSTRACT To investigate the origin of differences in previously published pulmonary function studies of workers in kaolin plants in Georgia, spirometric and radiographic data collected in a cross sectional survey of two large plants were analysed. As compared with workers in plant 2, workers in plant 1 had a $2 \cdot 7$-fold greater prevalence of pneumoconiosis and a mean 0.361 decrement in adjusted forced vital capacity. Our previous finding that exposure to kaolin was not associated with a decrement in lung function may have resulted from failure to consider differences between the plants.

Kaolin is a commercially valuable form of clay primarily composed of kaolinite, a non-fibrous hydrated aluminum silicate with low quartz content.' Kaolin is cytotoxic to erythrocytes ${ }^{2}$ and macrophages $^{34}$ in vitro. Middleton first reported radiographic abnormalities in kaolin processing workers in 1936. ${ }^{5}$ Pathological and mineralogical studies have confirmed the fibrogenic potential of kaolinite..$^{6-10}$ Epidemiological studies in the British, American, and Egyptian industries have found that the prevalence of opacities is related to duration of employment or to age. ${ }^{11-18}$

Three pulmonary function studies in the American industry have yielded different results. Sepulveda et al found differences in mean adjusted forced expiratory volume in one second $\left(\mathrm{FEV}_{1}\right)$, forced vital capacity (FVC), and peak flow between exposed and nonexposed workers. ${ }^{617}$ Altekruse $e t$ al found that FEV, \% predicted and FVC $\%$ predicted declined with increasing years of employment in production, and that FEV $\%$ predicted and FVC \% predicted were lower in production workers with pneumoconiosis as compared with production workers without pneumoconiosis. ${ }^{18}$ By contrast to these studies, which found that decrement in lung function was related to exposure to kaolin and to pneumoconiosis, Kennedy et al found no differences in mean adjusted $\mathrm{FEV}_{1}$ or FVC between workers with and without pneumoconiosis. ${ }^{15}$

In the present study we used previously collected data to test two hypotheses for the discrepant pulmonary function results. Plant differences in prevalence of pneumoconiosis and pulmonary function might result

Accepted 19 December 1988 from qualitative or quantitative differences in exposure to kaolin. In addition, Sepulveda et $\mathrm{l}^{1617}$ and Altekruse $e t a l^{18}$ examined the relation between exposure and lung function but Kennedy et al did not. ${ }^{15}$ Therefore, the discrepant results might be due to an independent association of exposure to kaolin with opacities and decrement in lung function (fig).

\section{Methods}

We reanalysed data from the two largest plants $(\mathrm{n}=$ 181 and 244) studied by Kennedy et al, the only study of the American industry which included more than one plant. ${ }^{15} \mathrm{~A}$ third plant was excluded owing to its small workforce $(n=34)$. Since the plants were near each other, lifetime work histories were collected to determine if workers currently employed in one plant had been previously employed in the other.

The crude relations of independent variables to dependent variables were tested using the chi-squared test with continuity correction for discrete variables and the two tailed $t$ test for continuous variables. Multiple regression was used to simultaneously adjust

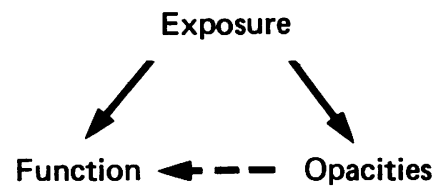

Schema of independent association of exposure with opacities and lung function. Solid lines represent strong associations, dotted line a weak association. 
Baser, Kennedy, Dodson, Rawlings, Rao, Hoidal $\stackrel{\underline{\underline{m}}}{\bar{c}}$

for potential explanatory and confounding variables. ${ }^{1920}$ Multiple linear regression was used for the continuous dependent variables (FEV 1 and FVC). The distributions of regression residuals were tested for normality and constant variance. ${ }^{21}{ }^{22}$ Multiple logistic regression was used for the dichotomous dependent variable (presence or absence of opacities). The chi-squared goodness of fit test was used to test fit to the regression model. ${ }^{19}$ Plant membership was included as an independent variable in the linear and logistic regressions to test for interplant differences in lung function and the prevalence of pneumoconiosis.

The independent variables in the multiple linear regression equations with $F E V_{1}$ and $F V C$ as the dependent variables were plant, years in production, age, height, race, and smoking status. Years in production was included to test the exposure-lung function hypothesis. Race and smoking status were included as independent variables because separate race and smoking status specific regression equations would have been based on small numbers of subjects.

The independent variables in the multiple logistic regression with presence of pneumoconiosis as the dependent variable were plant, age (dichomtomised by greater or less than 55), and years in production. Age over 55 was an independent correlate of the prevalence of pneumoconiosis. ${ }^{15}$ a finding believed to reflect higher historical dust concentrations. ${ }^{15} 18$ Employment in production, but not in maintenance, mine, laboratory, or administration, was associated with opacities. $^{15}$

\section{Results}

Table 1 compares the crude distributions of demographic and exposure variables by plant. Compared with workers in plant 2 , workers in plant 1 were significantly younger and had been employed for fewer years in production. There were no differences between plants
Table 1 Demographic and exposure variables by plant

\begin{tabular}{|c|c|c|c|c|c|c|}
\hline \multirow[b]{2}{*}{ Variable } & \multirow[b]{2}{*}{ Category } & \multicolumn{3}{|l|}{ Plant } & \multirow[b]{2}{*}{$\begin{array}{l}\text { Chi- } \\
\text { squared }\end{array}$} & \multirow[b]{2}{*}{$p$} \\
\hline & & $\begin{array}{l}l \\
(n=181)\end{array}$ & $\begin{array}{l}2 \\
(n=24\end{array}$ & 44) & & \\
\hline Age (y) & $\begin{array}{l}18-34 \\
35-49 \\
50-65\end{array}$ & $\begin{array}{r}119 \\
47 \\
15\end{array}$ & $\begin{array}{l}98 \\
73 \\
73\end{array}$ & & $37 \cdot 38$ & $<0.001$ \\
\hline Height (in) & $\begin{array}{l}62-67 \\
68-73 \\
74-78\end{array}$ & $\begin{array}{r}24 \\
139 \\
18\end{array}$ & $\begin{array}{r}34 \\
180 \\
30\end{array}$ & & 0.67 & 0.715 \\
\hline $\begin{array}{l}\text { Smoking } \\
\text { status }\end{array}$ & $\begin{array}{l}\text { Never } \\
\text { Ex } \\
\text { Current }\end{array}$ & $\begin{array}{l}50 \\
44 \\
87\end{array}$ & $\begin{array}{r}64 \\
64 \\
116\end{array}$ & 8 & 0.23 & 0.89 \\
\hline Race & $\begin{array}{l}\text { White } \\
\text { Black }\end{array}$ & $\begin{array}{r}124 \\
57\end{array}$ & $\begin{array}{r}169 \\
75\end{array}$ & $:$ & 0.03 & 0.868 \\
\hline $\begin{array}{l}\text { Employment in } \\
\text { production } \\
\text { (y) } \\
\text { Pneumo- } \\
\text { coniosis }\end{array}$ & $\begin{array}{l}0 \\
1-9 \\
\geqslant 10 \\
\text { Yes } \\
\text { No }\end{array}$ & $\begin{array}{r}99 \\
55 \\
27 \\
19 \\
162\end{array}$ & $\begin{array}{r}88 \\
98 \\
58 \\
21 \\
223\end{array}$ & & $\begin{array}{r}15 \cdot 03 \\
0.44\end{array}$ & $\begin{array}{r}<0.001 \\
0.623\end{array}$ \\
\hline
\end{tabular}

Table 2 Regression coefficients (b) and standard errors $\left(S E_{b}\right)$ for multiple logistic regression with presence of pneumoconiosis as the dependent variable

\begin{tabular}{|c|c|c|c|c|c|}
\hline $\begin{array}{l}\text { Independent } \\
\text { variable }\end{array}$ & $b$ & $S E_{b}$ & $b / S E_{b}$ & $\begin{array}{l}\text { Odds } \\
\text { ratio* }\end{array}$ & $p$ \\
\hline $\begin{array}{l}\text { Years in } \\
\text { production } \\
(\% / y) \\
\text { Aget } \\
\text { Plantł }\end{array}$ & $\begin{array}{l}0.071 \\
0.591 \\
0.987\end{array}$ & $\begin{array}{l}0.011 \\
0.268 \\
0.273\end{array}$ & $\begin{array}{l}6.45 \\
2 \cdot 20 \\
3.61\end{array}$ & $\begin{array}{l}1.1 \\
1.8 \\
2.7\end{array}$ & $\begin{array}{r}<0.001 \\
0.028 \\
<0.009\end{array}$ \\
\hline
\end{tabular}

in the crude distributions of height, smoking status, $\stackrel{2}{\varrho}$ race, or pneumoconiosis. Only one person in plant $2 \stackrel{\otimes}{2}$ had been previously employed in plant 1 .

Table 2 presents the results of the multiple logistic 3 regression with presence of pneumoconiosis as the $?$ outcome. The chi-squared goodness of fit test was not?

Table 3 Regression coefficients $(b)$ and standard errors $\left(S E_{b}\right)$ for multiple linear regressions with $F E V$, and $F V C$ as dependent? variables

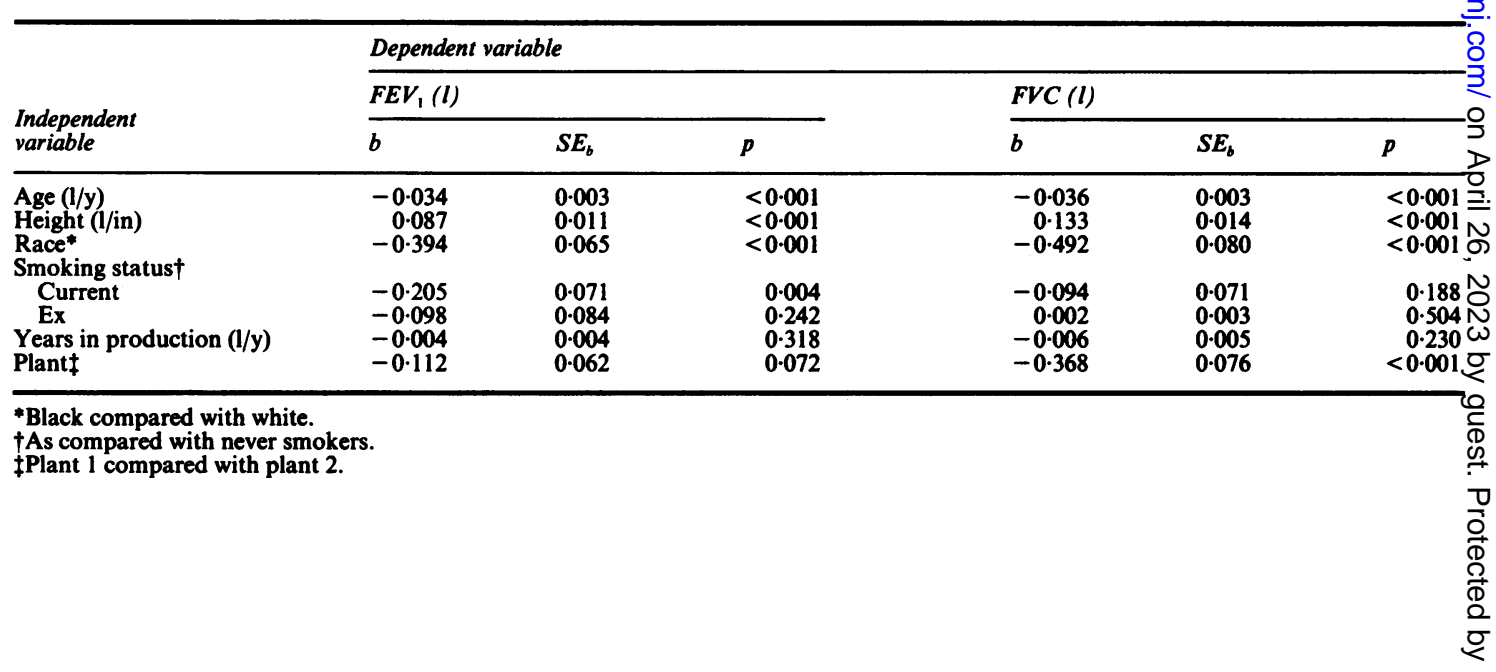


significant $(p=0 \cdot 125)$. The adjusted prevalence of pneumoconiosis was $1 \cdot 8$-fold greater in workers older than 55 as compared with workers aged 55 or under $(p$ $=0.028$ ). The adjusted prevalence of pneumoconiosis increased $1.1 \%$ for each year in production $(\mathrm{p}<$ 0.001 ), so that workers with 20 years employment in production would be expected to have an adjusted prevalence of $22 \%$. Even after adjusting for age and years in production, workers in plant 1 had a $2 \cdot 7$-fold greater prevalence than workers in plant $2(p<0.001)$.

Table 3 presents the results of the multiple linear regressions with FEV 1 and FVC as the outcomes. The regression residuals were normally distributed and had constant variance. The independent variables accounted for $48.8 \%$ of the variance in $\mathrm{FEV}_{1}$ and $47.1 \%$ of the variance in FVC. There was no relation between years in production and adjusted $\mathrm{FEV}_{1}$ or adjusted FVC. There was, however, a strong association of plant with adjusted FVC $(p<0.001)$ but not with adjusted $F_{1} V_{1}(p<0.072)$. Relative to workers in plant 2, workers in plant 1 had a mean 0.3681 decrement in adjusted FVC.

\section{Discussion}

Although years in production was not independently associated with opacities and decrement in lung function, workers in plant 1 (who were younger and had been employed for fewer years in production than workers in plant 2) had a significantly higher adjusted prevalence or pneumoconiosis and lower adjusted FVC. Possibly the regression procedures incompletely adjusted for the interplant differences in the distributions of years in production and age (table 1). If this were true, however, workers in plant 2 would have had a higher adjusted prevalence of pneumoconiosis and lower adjusted FVC.

The smoking histories did not include information on pack-years of smoking. Owing to the age differences between plants (table 1), the distributions of pack-years of smoking might differ even though the distributions of smoking status were similar. This may be important for several reasons. Impaired mucociliary clearance in smokers may result in increased dust retention and risk of pneumoconiosis. ${ }^{23}$ There was no relation, however, between smoking status and prevalence of pneumoconiosis. ${ }^{15}$ Oldham has suggested the use of interaction terms between age and smoking status when detailed smoking histories are not available. ${ }^{24}$ In these data interaction terms (between age and ex-smoking and between age and current smoking) did not explain variance in either $F_{1}$ or FVC in addition to that explained by other independent variables. In addition, cigarette smoking is more closely associated with obstructive than with restrictive pulmonary function changes, ${ }^{25}$ and we found a difference between plants in adjusted FVC but not in adjusted $\mathrm{FEV}_{1}$ (table 3 ). Thus it is unlikely that the lack of detailed smoking histories biased these results.

The results of this study differ from those of other studies reporting "mill effects" in the coal' ${ }^{26}$ and cotton $^{27}$ industries because the findings of both restrictive pulmonary function changes and an increased prevalence of pneumoconiosis in one plant suggest a responsible agent. Historically, $15-20 \%$ of the production of plant 1 has been calcined kaolin, whereas plant 2 has produced only hydrous clay (Production managers plants 1 and 2, personal communications). High temperature processing methods, such as those used to calcine kaolin or to make refractory brick, produce mineralogical changes in hydrous kaolin. When quartz is heated to temperatures between $867^{\circ} \mathrm{C}$ and $1470^{\circ} \mathrm{C}$ it is converted to cristobalite, which has a greater fibrogenic potential. ${ }^{28}$ Concentrations of cristobalite in air samples as high as $8.9 \%$ have been reported from a Missouri firebrick factory using kaolin. $^{29}$

Information on respirable particle size and concentration for calcined versus hydrous kaolin is lacking, and detailed information on output of calcined kaolin for the companies under study could not be obtained from the governmental agencies which routinely collect these data for the industry as a whole. Further studies of the industry should include this information, which is necessary for the attribution of differences in pulmonary function or radiographic abnormalities to historical exposures.

Supported by grant $\mathrm{OH} 02264-02$ from the National Institute of Occupational Safety and Health.

\section{References}

1 Anonymous. Kaolin in the US. Industrial Mining 1971;9:9-30.

2 Middleton EL. Industrial pulmonary disease due to the inhalation of dust. Lancet 1936;ii:59-64.

3 Wallace WE Jr, Vallyathan V, Keane MJ, Robinson V. In vitro biologic toxicity of native and surface modified silica and kaolin. J Toxicol Environ Health 1985;16:415-24.

4 Davies R. Factors involved in the cytotoxicity of kaolinite towards macrophages in vitro. Environ Health Perspect 1983;51:249-52.

5 Davies R, Griffiths DM, Johnson NF, Preece AW, Livingston DC. The cytotoxicity of kaolin towards macrophages in vitro. $\mathrm{Br} J$ Exp Pathol 1984;65:253-66.

6 Wagner JC, Pooley FD, Gibbs A, Lyons J, Sheers G, Moncrieff CB. Inhalation of china stone and china clay dusts: relationship between the mineralogy of dust retained in the lungs and pathological changes. Thorax 1986;41:190-6.

7 Hale LW, Gough J, King EJ, Nagelschmidt G. Pneumoconiosis of kaolin workers. Br J Ind Med 1956;13:251-9.

8 Lynch KM, McIver FA. Pneumoconiosis from exposure to kaolin dust: kaolinosis. Am J Pathol 1954;30:1117-27.

9 Lapenas D, Gale P, Kennedy T, Rawlings Jr W, Dietrich P. Kaolin pneumoconiosis: radiologic, pathologic, and mineralogic findings. Am Rev Respir Dis 1984;130:282-8. 
10 Lapenas PJ, Gale PN. Kaolin pneumoconiosis: a case report. Arch Pathol Lab Med 1983;107:650-3.

11 Edenfield RW. A clinical and roentgenological study of kaolin workers. Arch Environ Health 1960;5:392-403.

12 Sheers F. Prevalence of pneumoconiosis in Cornish kaolin workers. Br J Ind Med 1964;21:218-25.

13 Warraki S, Herant Y. Pneumoconiosis in china clay workers. $\mathrm{Br} J$ Ind Med 1963;20:226-30.

14 Oldham PD. Pneumoconiosis in Cornish china clay workers. Br J Ind Med 1983;40:131-7.

15 Kennedy T, Rawlings W Jr, Baser M, Tockman M. Pneumoconiosis in Georgia kaolin workers. Am Rev Respir Dis 1983;127:215-20.

16 Sepulveda M-J, Vallyathan V, Attfield MD, Piacitelli L, Tucker JH. Pneumoconiosis and lung function in a group of kaolin workers. Am Rev Respir Dis 1983;127:231-5.

17 Sepulveda M-J, Attfield MD, Vallyathan V, Piacitelli L, Tucker J. Kaolin and the lung. Am Rev Respir Dis 1983;128:211-2.

18 Altekruse EB, Chaudhary BA, Pearson MG, Morgan WKC. Kaolin dust concentrations and pneumoconiosis at a kaolin mine. Thorax 1984;39:436-41.

19 Snedecor GW, Cochran WG. Statistical methods. 6th ed. Ames: Iowa State University Press, 1967.
Baser, Kennedy, Dodson, Rawlings, Rao, Hoida [

20 Schlesselman JJ. Case control studies: design, conduct, analysis $\overline{\bar{Q}}$ New York: Oxford University Press, 1982.

21 Draper N, Smith H. Applied regression analysis. 2nd ed. New York: John Wiley and Sons, 1981.

22 Anscombe FJ, Tukey JW. The examination and analysis of: residuals. Technometrics 1963;5:141-60.

23 Cohen DF, Arai SF, Brain JD. Smoking impairs long-term dusf clearance from the lung. Science 1979;204:514-7.

24 Oldham PD. Decline of FEV, Thorax 1987;42:161-4.

25 US Department of Health and Human Services. The healt consequences of smoking: chronic obstructive lung disease. AD report of the Surgeon General. Washington: US Governmen? Printing Office, 1984.

26 Hurley JF, Burns J, Copland L, Dodson J, Jacobsen M. Coalworkers' simple pneumoconiosis and exposure to dust at 10 British coalmines. Br J Ind Med 1982;39:120-7.

27 Jones RN, Diem JE, Glindmeyer H, et al. Mill effect and dose $\vec{\omega}$ response relationships in byssinosis. $\mathrm{Br} J$ Ind Med 1979;36? 305-13.

28 Parkes WR. Occupational lung disorders. 2nd ed. London: Butter worths, 1982.

29 Lesser M, Zia M, Kilburn K. Silicosis in kaolin workers and firebrick makers. Southern Journal of Medicine 1978;71:1242-6.

\section{Destruction of manuscripts}

From 1 July 1985 articles submitted for publication will not be returned. Authors whose papers are rejected will be advised of the decision and the manuscripts will be kept under security for three months to deal with any inquiries and then destroyed. 